\title{
Mineralogy and genesis of kimberlite-hosted chloride-containing nodules from Udachnaya-East pipe, Yakutia, Russia
}

\author{
Victor V. Sharygin ${ }^{1}$, Vadim S. Kamenetsky², Maya B. Kamenetsky ${ }^{2}$ and Alexander V. \\ Golovin ${ }^{1}$ \\ ${ }^{1}$ V.S.Sobolev Institute of Geology and Mineralogy, Siberian Branch of Russian Academy of Sciences, \\ Novosibirsk, Russia \\ ${ }^{2}$ CODES and School of Earth Sciences, University of Tasmania, Hobart, TAS, Australia
}

\begin{abstract}
Abundant chloride-bearing nodules have been recently described in the diamondiferous UdachnayaEast pipe in Yakutia (Kamenetsky et al., 2006; 2007a). They occur in the deep levels of the pipe $(>350 \mathrm{~m})$ in exceptionally fresh kimberlites (Marshintsev et al., 1976). The lack of secondary, alteration-related minerals in these Udachnaya-East kimberlites (UEK) is associated with an essentially carbonate-chloride groundmass and the presence of chloride-bearing nodules (Kamenetsky et al., 2004, 2006, 2007a; Sharygin et al., 2007b). The shapes and sizes of chloride-bearing nodules and segregations are variable, from spherical and round to angular and from 0.5 to 30 $\mathrm{cm}$ in diameter, rarely up to $1 \mathrm{~m}$. The contacts of the nodules with the host kimberlite are sharp $(<1 \mathrm{~mm})$, without evidence of thermometamorphic effects. In some cases, the contact zone is composed of a breccialike aggregate of olivine, calcite, $\mathrm{Na}-\mathrm{Ca}$ carbonates, sodalite, phlogopite-tetraferriphlogopite, humiteclinohumite, perovskite, apatite, $\mathrm{Fe}-\mathrm{Ti}$ oxides, djerfisherite and alkali sulfates set in a matrix of chlorides (Kamenetsky et al., 2006, 2007a).
\end{abstract}

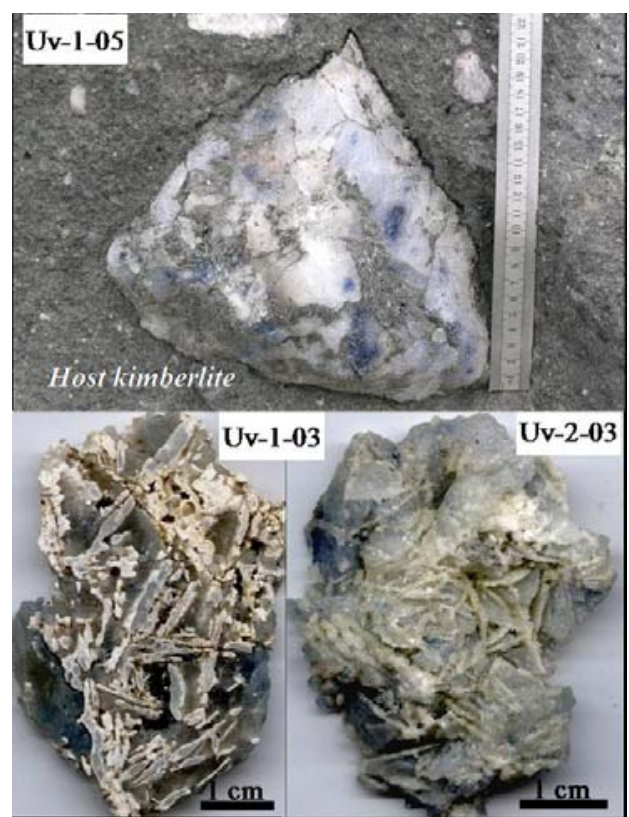

Fig. 1. Chloride (Uv-1-05), chloride-"nyerereite" (Uv-1-03) and chloride-shortite-northupite-calcite (Uv-2-03) varieties of nodules.
The mineral assemblage of the nodules is dominated by chlorides, and the chloride-rich $(>90-95 \% \mathrm{NaCl}+\mathrm{KCl})$ varieties are most common. Chloride-carbonate $(\sim 50 \%$ $\mathrm{NaCl}+\mathrm{KCl}), \quad$ chloride-carbonate-silicate $\quad(50-70 \%$ $\mathrm{NaCl}+\mathrm{KCl})$, and carbonate-rich species $(<10 \%$ $\mathrm{NaCl}+\mathrm{KCl}$ ) are less common (Fig. 1, Kamenetsky et al., 2006, 2007a). Halite is predominated over sylvite. The latter mineral is commonly localized as amoeboid blebs in halite or as individual grains among halite grains. Rarely halite occurs as blebs in sylvite grains (Fig. 2).

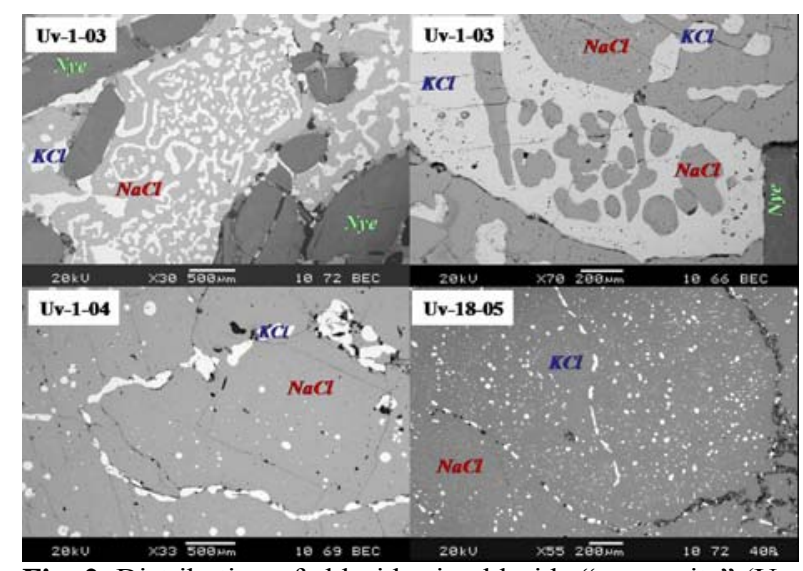

Fig. 2. Distribution of chlorides in chloride-"nyerereite" (Uv1-03) and chloride (Uv-1-04, Uv-18-05) varieties of nodules. Nye - "nyerereite". BSE images.

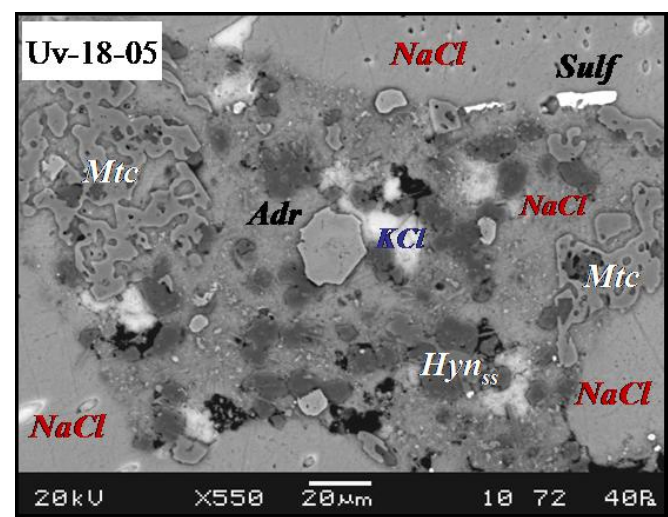

Fig. 3. Fine-grained interstitial aggregate in a chloride nodule Sulf - sulfides (pyrrhotite+djerfisherite), Mtc - monticellite, Adr - Ti-andradite; $\mathrm{Hyn}_{\mathrm{ss}}$ - haüyne solid solution. BSE image. 
In addition to chloride and carbonate components, the presence of fine-grained aggregate of chlorides, silicates, carbonates and sulfates \pm sulfides (1-5 vol.\%, rarely - up to $30 \mathrm{vol} \%$ in chloride-carbonate-silicate species) is typical of the nodules. In individual samples of essentially chloride species such aggregates vary from chloride-sulfate-silicate to chloride-carbonatesilicate in composition, and are commonly localized among chloride grains (Fig. 3). Minerals found in the nodules are listed in Table 1 in comparison with kimberlite groundmass and olivine-hosted melt inclusions. It should be noted that mineral species in chloride-bearing nodules occur wider than in host kimberlites and melt inclusions in olivine. The findings of wollastonite, diopside, Ti-andradite, monticellite and haüyne in essentially chloride nodules indicate their high-temperature origin.

The chloride-carbonate nodules are most remarkable, as they are composed of "nyerereite" (Na-K-Ca-S carbonate) and shortite-northupite-calcite varieties. Halite, sylvite, zoned "nyerereite", shortite, aphthitalite and rasvumite are the main minerals in the chloride"nyerereite" nodules. Zoned "nyerereite" crystals (up to $5 \mathrm{~cm}$ ) have spongy rims consisting of shortite, aphthitalite and calcite (Fig. 4). The central part of these crystals is a Na-K-Ca-S-carbonate resembling nyerereite and zemkorite, but having distinct a XRD pattern.

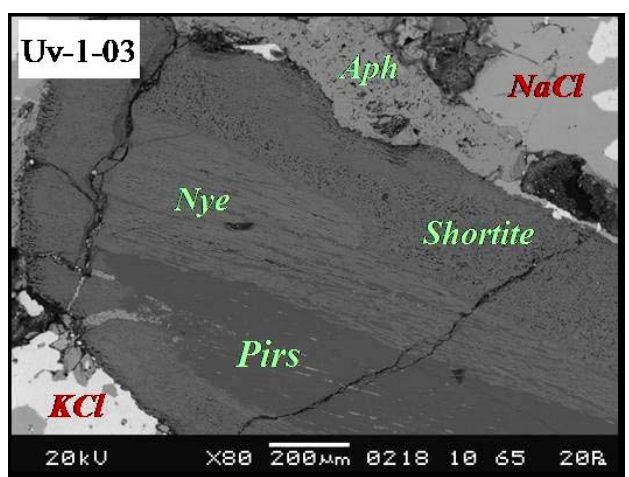

Fig. 4. Zoned "nyerereite" crystal with shortite-rich rim and partial replacement of "nyerereite" by pirssonite, chloride"nyerereite" nodule. Aph - aphthitalite, Pirs - pirssonite.

Chloride-shortite-northupite-calcite nodules contain different minor phases, which are localized on the contact of chlorides and carbonates or as crystal inclusions in carbonates. These phases are aphthitalite, phlogopite-tetraferriphlogopite, apatite, djerfisherite, Na-sulfates, Ca-Ba-Sr-sulfates and carbonates (alstonite-paralstonite, olekminskite, barite, celestine), galena, $\mathrm{Cu}$-sulfides and bradleyite.

The minerals of the nodules are prone to alteration, with complete degradation observed under surface conditions. The water-soluble chlorides and alkali sulfates are dissolved, whereas alkali carbonates are replaced by pirssonite, $\mathrm{Na}_{2} \mathrm{Ca}\left(\mathrm{CO}_{3}\right)_{2} \cdot 2 \mathrm{H}_{2} \mathrm{O}$, and other $\mathrm{H}_{2} \mathrm{O}$-bearing carbonates (up to trona), and a Fe-rich oxidized coating is developed on the surface of the $\mathrm{K}$ sulfides. Similar alteration has been described as typical of the Oldoinyo Lengai natrocarbonatites (Mitchell, 2006; Zaitsev, Keller, 2006).

Table 1. Comprehensive data for the Udachnaya-East minerals found in chloride-bearing nodules (ND), kimberlite groundmass (KG) and melt inclusions in kimberlite olivines (MI).

\begin{tabular}{|c|c|c|c|c|}
\hline Mineral & Formula & ND & KG & MI \\
\hline \multicolumn{5}{|l|}{ Sulfides } \\
\hline Pyrrhotite & $\mathrm{Fe}_{1-\mathrm{x}} \mathrm{S}$ & $\mathrm{x}$ & $\mathrm{x}$ & $\mathrm{x}$ \\
\hline Pentlandite & $(\mathrm{Fe}, \mathrm{Ni})_{9} \mathrm{~S}_{8}$ & & $*$ & \\
\hline Chalcopyrite & $\mathrm{CuFeS}_{2}$ & * & $*$ & \\
\hline Djerfisherite & $\mathrm{K}_{6} \mathrm{Na}_{0-1}(\mathrm{Fe}, \mathrm{Ni}, \mathrm{Cu})_{24} \mathrm{~S}_{26} \mathrm{Cl}$ & $\mathrm{x}$ & $\mathrm{x}$ & $\mathrm{X}$ \\
\hline Rasvumite & $\mathrm{KFe}_{2} \mathrm{~S}_{3}$ & $\mathrm{X}$ & $\mathrm{x}$ & \\
\hline Galena & $\mathrm{PbS}$ & $*$ & & \\
\hline Sphalerite & $\mathrm{ZnS}$ & $*$ & $*$ & \\
\hline \multicolumn{5}{|l|}{ Chlorides } \\
\hline Halite & $\mathrm{NaCl}$ & $\mathrm{X}$ & $\mathrm{x}$ & $\mathrm{X}$ \\
\hline Sylvite & $\mathrm{KCl}$ & $\mathrm{X}$ & $\mathrm{x}$ & $\mathrm{X}$ \\
\hline \multicolumn{5}{|l|}{ Carbonates } \\
\hline Calcite & $\mathrm{CaCO}_{3}$ & $\mathrm{X}$ & $\mathrm{X}$ & $\mathrm{X}$ \\
\hline Dolomite & $\mathrm{CaMg}\left(\mathrm{CO}_{3}\right)_{2}$ & & $*$ & $*$ \\
\hline Siderite - Magnesite & $\mathrm{FeCO}_{3}-\mathrm{MgCO}_{3}$ & & & $*$ \\
\hline Shortite & $\mathrm{Na}_{2} \mathrm{Ca}_{2}\left(\mathrm{CO}_{3}\right)_{3}$ & $\mathrm{X}$ & $\mathrm{x}$ & $\mathrm{x}$ \\
\hline Zemkorite-Nyerereite & $(\mathrm{Na}, \mathrm{K})_{2} \mathrm{Ca}\left(\mathrm{CO}_{3}\right)_{2}$ & $\mathrm{X}$ & $\mathrm{x}$ & $\mathrm{X}$ \\
\hline Northupite & $\mathrm{Na}_{3} \mathrm{Mg}\left(\mathrm{CO}_{3}\right)_{2} \mathrm{Cl}$ & $\mathrm{X}$ & & $\mathrm{x}$ \\
\hline Alstonite - Paralstonite & $\mathrm{BaCa}\left(\mathrm{CO}_{3}\right)_{2}$ & $\mathrm{x}$ & & \\
\hline Olekminskite & $\mathrm{Sr}(\mathrm{Sr}, \mathrm{Ca}, \mathrm{Ba})\left(\mathrm{CO}_{3}\right)_{2}$ & * & & \\
\hline \begin{tabular}{|l|} 
Nahcolite \\
\end{tabular} & $\mathrm{NaHCO}_{3}$ & & & $*$ \\
\hline Pirssonite & $\mathrm{Na}_{2} \mathrm{Ca}\left(\mathrm{CO}_{3}\right)_{2} 2 \mathrm{H}_{2} \mathrm{O}$ & $\mathrm{x}$ & $\mathrm{x}$ & * \\
\hline Gaylussite & $\mathrm{Na}_{2} \mathrm{Ca}\left(\mathrm{CO}_{3}\right)_{2} \cdot 5 \mathrm{H}_{2} \mathrm{O}$ & $*$ & * & \\
\hline Trona & $\mathrm{Na}_{3}\left(\mathrm{CO}_{3}\right)\left(\mathrm{HCO}_{3}\right) 2 \mathrm{H}_{2} \mathrm{O}$ & $\mathrm{x}$ & & \\
\hline \multicolumn{5}{|l|}{ Sulfates } \\
\hline Aphthitalite & $\mathrm{NaK}_{3}\left(\mathrm{SO}_{4}\right)_{2}$ & $\mathrm{X}$ & $*$ & $\mathrm{X}$ \\
\hline Schairerite & $\mathrm{Na}_{21}\left(\mathrm{SO}_{4}\right)_{7} \mathrm{~F}_{6} \mathrm{Cl}$ & $\mathrm{x}$ & & \\
\hline Barite & $\mathrm{BaSO}_{4}$ & $\mathrm{x}$ & & \\
\hline Celestine & $\mathrm{SrSO}_{4}$ & $*$ & & \\
\hline Anhydrite & $\mathrm{CaSO}_{4}$ & $*$ & & \\
\hline Syngenite & $\mathrm{K}_{2} \mathrm{Ca}\left(\mathrm{SO}_{4}\right)_{2} \mathrm{H}_{2} \mathrm{O}$ & $*$ & & $*$ \\
\hline \multicolumn{5}{|l|}{ Phosphates } \\
\hline Apatite & $\mathrm{Ca}_{5}\left(\mathrm{PO}_{4}\right)_{3}(\mathrm{~F}, \mathrm{OH})$ & $\mathrm{x}$ & $\mathrm{x}$ & $*$ \\
\hline Bradleyite & $\mathrm{Na}_{3} \mathrm{Mg}\left(\mathrm{PO}_{4}\right)\left(\mathrm{CO}_{3}\right)$ & * & & \\
\hline \multicolumn{5}{|l|}{ Oxides } \\
\hline Rutile & $\mathrm{TiO}_{2}$ & & $\mathrm{x}$ & \\
\hline Perovskite & $\mathrm{CaTiO}_{3}$ & $*$ & $\mathrm{X}$ & $*$ \\
\hline Chromite & $(\mathrm{Fe}, \mathrm{Mg})(\mathrm{Cr}, \mathrm{Al})_{2} \mathrm{O}_{4}$ & $*$ & $\mathrm{X}$ & $*$ \\
\hline Ti-magnetite & $(\mathrm{Fe}, \mathrm{Mg})(\mathrm{Fe}, \mathrm{Ti})_{2} \mathrm{O}_{4}$ & $*$ & $\mathrm{X}$ & $*$ \\
\hline Magnetite & $\mathrm{FeFe}_{2} \mathrm{O}_{4}$ & $\mathrm{x}$ & $\mathrm{X}$ & $\mathrm{X}$ \\
\hline Ilmenite - Pyrophanite & $(\mathrm{Fe}, \mathrm{Mn}, \mathrm{Mg}) \mathrm{TiO}_{3}$ & $\mathrm{x}$ & $\mathrm{x}$ & $\mathrm{x}$ \\
\hline $\mathrm{SiO}_{2}$ polymorph & $\mathrm{SiO}_{2}$ & $*$ & & \\
\hline Brucite & $\mathrm{Mg}(\mathrm{OH})_{2}$ & $*$ & & \\
\hline \multicolumn{5}{|l|}{ Silicates } \\
\hline Phlogopite & $\mathrm{KMg}_{3} \mathrm{AlSi}_{3} \mathrm{O}_{10}(\mathrm{~F}, \mathrm{OH})_{2}$ & $\mathrm{x}$ & $\mathrm{X}$ & $\mathrm{X}$ \\
\hline Tetraferripholopite & $\mathrm{KMg}_{3} \mathrm{FeSi}_{3} \mathrm{O}_{10}(\mathrm{OH})_{2}$ & $*$ & $*$ & $\mathrm{X}$ \\
\hline Diopside-Hedenbergite & $\mathrm{Ca}(\mathrm{Mg}, \mathrm{Fe}) \mathrm{Si}_{2} \mathrm{O}_{6}$ & $*$ & $*$ & $*$ \\
\hline Wollastonite & $\mathrm{CaSiO}_{3}$ & $*$ & & \\
\hline Humite-Clinohumite & $(\mathrm{Mg}, \mathrm{Fe})_{7}\left(\mathrm{SiO}_{4}\right)_{3}(\mathrm{~F}, \mathrm{OH})_{2}$ & $\mathrm{x}$ & & $\mathrm{x}$ \\
\hline Ti-garnet & $\mathrm{Ca}_{3}(\mathrm{Fe}, \mathrm{Ti}, \mathrm{Al})_{2}\left(\mathrm{SiO}_{4}\right)_{3}$ & $*$ & & \\
\hline Cuspidine & $\mathrm{Ca}_{4} \mathrm{Si}_{2} \mathrm{O}_{7} \mathrm{~F}_{2}$ & $*$ & & \\
\hline Sodalite-Haüyne $_{\text {ss }}$ & $\mathrm{Na}_{8} \mathrm{Al}_{6} \mathrm{Si}_{6} \mathrm{O}_{24} \mathrm{Cl}_{2}$ & $*$ & $*$ & $*$ \\
\hline Olivine & $(\mathrm{Mg}, \mathrm{Fe})_{2} \mathrm{SiO}_{4}$ & $\mathrm{x}$ & $\mathrm{X}$ & $\mathrm{x}$ \\
\hline Monticellite & $\mathrm{Ca}(\mathrm{Mg}, \mathrm{Fe}) \mathrm{SiO}_{4}$ & * & $*$ & * \\
\hline
\end{tabular}

Note: X - main; x - minor (1-5\%);* - accessory. New author's data and data from Egorov et al. (1988), Kornilova et al. (1998), Golovin et al. (2007), Sharygin et al. (2007a-b), Kamenetsky et al. (2004, 2006, 2007a). 


\section{Origin of chloride-bearing nodules}

Chloride minerals and chloride-bearing nodules in the UEK groundmass represent a petrological oddity, the origin of which can be important in understanding petrogenesis and emplacement of kimberlite magmas. In the first paper describing chlorides in the Siberian kimberlites their origin was a priori ascribed to postmagmatic crystallization from the platform brines (Pavlov, Ilupin 1973). The weakness of such idea is that platform brines cause strong alteration in kimberlites, whereas the studied UEK samples have no serpentine or other low-temperature hydrous silicates. In contrast, the UEK chloride and chloride-carbonate nodules are essentially water-free, and their mineral assemblage (e.g., presence of "nyerereite", phlogopite, olivine, Ca-silicates and K-sulfides; see Table 1) strongly supports high-temperature crystallization (Kamenetsky et al., 2004, 2006, 2007a-b; Golovin et al., 2007; Sharygin et al., 2007a-b). Another model considered contamination of the kimberlite magma by platform brines during emplacement (Egorov et al., 1988; Kornilova et al., 1998). However, such process should inevitably result in formation of abundant $\mathrm{H}_{2} \mathrm{O}-$ rich minerals and further autometasomatic reactions. The UEK and chloride-bearing nodules contain one potentially $\mathrm{H}_{2} \mathrm{O}$-bearing mineral, phlogopite, but its abundance is low ( $<5$ vol. $\%)$.

Two other scenarios can be responsible for hightemperature origin of chlorides in the UEK. The chloride-bearing nodules may represent fragments of evaporites entrapped by and reacted with the kimberlite magma. Such mechanism is possible for some kimberlite pipes from the southern Siberian craton (e.g. Mir and Internatsional'naya pipes), where evaporites (halite and dolomite lithologies) are dominant among country rocks. This is not the case for the sedimentary sequence around the Udachnaya pipe (Zinchuk, 2000), even at significant depths (up to $2000 \mathrm{~m}$ ). Small lenses of halite $(5-10 \mathrm{~cm})$ were recorded in large carbonate blocks within the UEK (N.P. Pokhilenko, pers. comm.), but these cannot be taken as ample evidence of wider occurrence of chlorides in local sediments. Moreover, our samples lack borate minerals and bitumen (or products of their pyrolysis) that are typical of the Siberian evaporites.

Our preferred model considers the formation of chloride-bearing assemblages at the latest evolutionary stages of the kimberlite magma (Golovin et al., 2007; Kamenetsky et al., 2004, 2006, 2007a-b; Sharygin et al., 2007a-b) and mantle origin of chlorine in the UEK (Maas et al., 2005). Earlier crystallization of olivine drives the residual melt towards essentially "dry" and non-silicate compositions, as recorded by melt inclusions in the UEK olivine (Golovin et al., 2007; Kamenetsky et al., 2004, 2007a), that crystallize calcite, alkali carbonates, chlorides, sulfates and potassium sulfides at temperatures $<800^{\circ} \mathrm{C}$.

This work was supported by RFBR (grant 07-05-00072) and $S B$ RAS (integration project 6.15) and funding from the Australian Research Council to VSK and CODES Centre of Excellence in Ore Deposits.

\section{References}

Egorov, K.N., Ushchapovskaya, Z.F., Kashaev, A.A., Bogdanov, G.V., Sizykh, I.I., 1988. Zemkorite - a new carbonate from Yakutian kimberlites. Doklady Akademii Nauk SSSR, 301, 188-192.

Golovin, A.V., Sharygin, V.V., Pokhilenko, N.P., 2007. Melt inclusions in olivine phenocrysts in unaltered kimberlites from the Udachnaya-East Pipe, Yakutia: some aspects of kimberlite magma evolution during late crystallization stages. Petrology, 15, 168-183.

Kamenetsky, M.B., Sobolev, A.V., Kamenetsky, V.S., Maas, R., Danyushevsky, L.V., Thomas, R., Sobolev, N.V., Pokhilenko, N.P., 2004. Kimberlite melts rich in alkali chlorides and carbonates: a potent metasomatic agent in the mantle. Geology, 32, 845-848.

Kamenetsky, V.S., Sharygin, V.V., Kamenetsky, M.B., Golovin, A.V., 2006. Chloride-carbonate nodules in kimberlites from the Udachnaya pipe: alternative approach to the evolution of kimberlite magmas. Geochemistry International, 44, 935-940.

Kamenetsky, V.S., Kamenetsky, M.B., Sharygin, V.V., Faure, K., Golovin, A.V., 2007a. Chloride and carbonate immiscible liquids at the closure of the kimberlite magma evolution (Udachnaya-East kimberlite, Siberia). Chemical Geology, 237, 384-400.

Kamenetsky, V.S., Kamenetsky, M.B., Sharygin, V.V., Golovin, A.V., 2007b. Carbonate-chloride enrichment in fresh kimberlites of the Udachnaya-East kimberlite, Siberia: A clue to physical properties of kimberlite magmas? Geophysical Research Letters, 34, L09316.

Kornilova, V.P., Egorov, K.N., Safronov, A.F., Filippov, N.D., Zaitsev, A.I., 1998. Monticellite kimberlite from the Udachnaya-East pipe and some aspects fro evolution of kimberlite melts. Otechestvennaya Geologiya, 1, 48-51.

Maas, R., Kamenetsky, M.B., Sobolev, A.V., Kamenetsky, V.S., Sobolev, N.V., 2005. Sr, Nd, and $\mathrm{Pb}$ isotope evidence for a mantle origin of alkali chlorides and carbonates in the Udachnaya kimberlite, Siberia. Geology, 33, 549-552.

Marshintsev, V.K., Migalkin, K.N., Nikolaev, N.C., Barashkov, Y.P., 1976. Unaltered kimberlite of the Udachnaya-East pipe. Doklady Akademii Nauk SSSR, 231, 961-964.

Mitchell, R.H., 2006. Mineralogy of stalactites formed by subaerial weathering of natrocarbonatite hornitos at Oldoinyo Lengai, Tanzania. Mineralogical Magazine, 70, 437-444.

Pavlov, D.I., Ilupin, I.P., 1973. Halite in the Yakutian kimberlites: its relationships with serpentine and question about source of solutions precipitated it. Doklady Akademii Nauk SSSR, 213, 1406-1409.

Sharygin, V.V., Golovin, A.V., Pokhilenko, N.P., Kamenetsky, V.S., 2007a. Djerfisherite in the Udachnaya-East pipe kimberlites (Sakha-Yakutia, Russia): paragenesis, composition and origin. European Journal of Mineralogy, 19, 51-63.

Sharygin, V.V., Kamenetsky, V.S., Kamenetskaya, M.B., Seretkin, Yu.V., Pokhilenko, N.P., 2007b. Rasvumite from the Udachnaya-East pipe, Yakutia: the first finding in kimberlites. Doklady Earth Sciences, 415A, 929-934.

Zaitsev, A.N., Keller J., 2006. Mineralogical and chemical transformation of Oldoinyo Lengai natrocarbonatites, Tanzania. Lithos, 91, 191-207.

Zinchuk, N.N., 2000. Postmagmatic minerals of kimberlites. Nedra, Moscow. 